\title{
Noise Impact on Inhabitants in Residential Areas under Various Anti- Noise Measures
}

\author{
V. Křivánek*, A. Pávková \\ Transport Research Centre, Brno, Czech Republic, \\ *Corresponding author: vitezslav.krivanek@cdv.cz
}

DOI: $10.2478 / \mathrm{v} 10158-012-0039-7$

\begin{abstract}
The sound environment is an inseparable part of the living environment. Noise is generally considered to be any sound or sounds which are undesirable, disturbing or harmful to people. Road transport has been the dominant source of noise in the environment for a number of years. Traffic noise modelling is used particularly for assessing the acoustic situation in the vicinity of roads, the identification of noise impact on population, designing anti-noise measures, strategic noise mapping, and action plans.

Regarding noise impact within the assessment of sustainable transport development, the programme SoundPLAN assessed different types of noise impact on inhabitants in residential areas through the use of alternatives such as the reduction of vehicle speed, construction of anti-noise barriers, installation of low-noise road surface, and various combinations of these. For the production of noise maps, input data was combined with geographic data or map materials respectively, data on buildings, roads, inhabitants, and traffic data.

The article presents the results of calculations of equivalent levels of acoustic pressure together with the division of impact on population into individual zones. Calculations are simulated on a terrain model of a part of the residential area surrounded by a busy trunk road and for the daytime. The residential area consists of detached houses and blocks of flats with a maximum height of 5 floors with the usual community amenities - garages, small shops, etc. Therefore, the application of simulated anti-noise measures may lead to a reduction of the negative impacts on the environment as well as on human health.
\end{abstract}

KEY WORDS: Anti-noise measures, road noise impact on inhabitants, SoundPLAN.

\section{INTRODUCTION}

On the topic of the noise impact within the assessment of sustainable transport development, the programme SoundPLAN assessed different types of noise impact on inhabitants in urban areas under such alternatives as the reduction of vehicle speed (Striegler et al., 2009), construction of anti-noise barriers, installation of low-noise road surface (Křivánek et al., 2012), and various combinations of these. For the production of noise maps, the input data was combined with geographic data or map materials respectively, data on buildings, roads, inhabitants, and traffic data. 


\section{CALCULATION SOFTWARE SOUNDPLAN}

Traffic noise modelling is particularly used for: assessing the acoustic situation in the vicinity of roads, identification of noise impact on inhabitants, designing anti-noise measures, strategic noise mapping, and action plans.

The software is produced by Braunstein+Berndt $\mathrm{GmbH}$; its use for acoustic calculation was approved by the National Reference Laboratory for communal noise at the Hygienic Station in Ústí nad Orlicí in July 1997. This software allows the modelling of the assessed area according to the current situation and the calculation of an isophone field in accordance with the given traffic technology (Braunstein+Berndt $\mathrm{GmbH}, 2008$ ). After running the software, several modules of options are offered, see Figure 1.

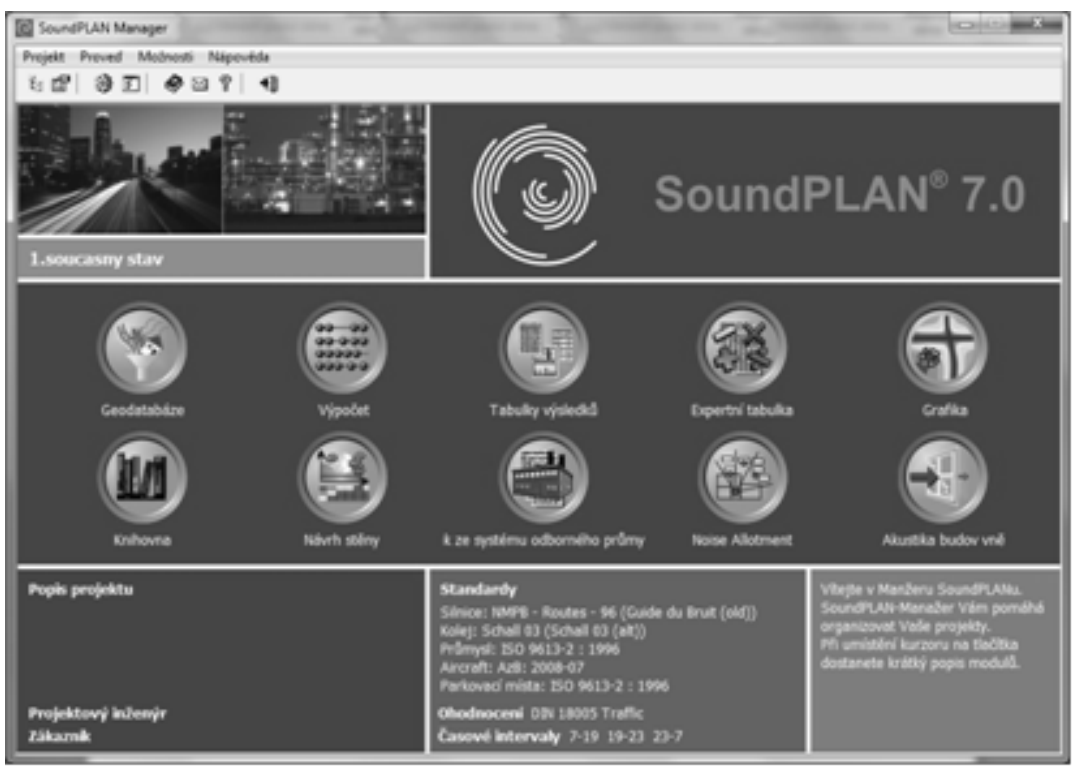

Figure 1: SoundPLAN manager after opening.

\subsection{Input data}

- Geographic data or mapping materials:

- topography and altimetry;

- orthophotomap.

- Information about buildings:

- position of buildings;

- ground plan, height of buildings and number of floors.

- Data on roads:

- routes of roads and railways;

- road, railway profile;

- type of road surface, rail track structure;

- bridges, tunnels, etc.

- Data on inhabitants:

- number of inhabitants in the monitored area is mentioned;

- number of inhabitants per one address point, average number of inhabitants per one address point, etc. 
- Data on industrial noise sources:

- location and parameters of noise sources.

- Traffic data:

- 24-hour traffic volume, train lengths, number of take-offs and landings of airplanes;

- time division of traffic volumes into daytime (6 - $22 \mathrm{~h})$ and night time (22 - $6 \mathrm{~h})$;

- composition of traffic flow - types of vehicles, trains, airplanes;

- travel speeds in different road segments.

\subsection{Output data}

The output consists of data assessment providing summarizing overviews of the outdoor noise from road traffic and industry in a monitored area which can be used as material for the preparation of land-use planning documentation, or for informing the public on the condition of the environment. In compliance with the current legislation, the only binding descriptor to describe the condition of the acoustic situation in a certain area is the equivalent level of acoustic pressure $A\left(L_{\text {Aeq }}\right)$ (Act no. 272/2011 Sb.; Act no. 258/2000 Sb.).

\subsection{Noise modeling}

The accuracy of the calculation results is particularly based on the accuracy and quality of the input data. It needs to be taken into account that any calculation software is just a powerful tool for the modelling of an acoustic situation. The accuracy of the calculation of noise maps is limited by the geographic accuracy of commonly available mapping materials and other input data (FEHRL, 2008). Regarding the digital mapping model ZABAGED 1: 10 000, the root mean square error (root mean square error not the maximum deviation) for points clearly identifiable in terrain (railways, roads, buildings, etc.) is estimated at approx. $5 \mathrm{~m}$. The impact of other changes of basic input parameters of calculations on emission values $L_{\text {Aeq }}$ is shown in Table 1 (Ládyš et al., 2006).

In order for the calculation method or the software product used for the calculation of noise in an area to be acceptable, the calculations need to show the results in the same accuracy level as can be attained through field measurements (Methodological guidance of the measurement and evaluation of noise in an out-working environment, 2001). The difference of value $L_{\text {Aeq }}$ from the conventionally correct value $L_{\text {Aeq }}$ should not exceed $2 \mathrm{~dB}$, i.e. the total uncertainty of the calculation model $+/-2 \mathrm{~dB}$. With the approved methodologies for calculations for individual types of noise it is possible to reach this value on the basis of a sufficient precision of the input data.

Table 1: Value of the next error of noise map calculation on the basis of inaccurate input data (Ládyš et al., 2006).

\begin{tabular}{|l|c|c|}
\hline Calculation input & Input change & Value change $\boldsymbol{L}_{\text {Aeq }}$ \\
\hline Traffic volume & $+/-10 \%$ & $+/-0.4 \mathrm{~dB}$ \\
\hline Traffic flow composition & $+/-5 \% \mathrm{NA}$ & $+/-0.5 \mathrm{~dB}$ \\
\hline Traffic flow speed & $+/-10 \%$ & $+/-0.8 \mathrm{~dB}$ \\
\hline Road alignment & $+/-1 \%$ (both ways) & $+/-0.3 \mathrm{~dB}$ \\
\hline Surface type & Ac (F3 $=1.1)$ & $+/-0.4 \mathrm{~dB}$ \\
\hline
\end{tabular}




\subsection{Alternatives of calculation of equivalent noise levels and impact on population}

Calculations of equivalent noise levels, whose source is only road traffic in urban areas, and the impact on the population at a certain level of exposition, were performed for the following situations during the daytime:

Speed reduction alternative:

- 1A) Calculation of the "current situation" - all roads speed $50 \mathrm{~km} / \mathrm{h}$;

- 1B) Calculation of the "current situation" - trunk roads $50 \mathrm{~km} / \mathrm{h}$, urban roads speed 30 $\mathrm{km} / \mathrm{h}$;

- 1C) Calculation of the "current situation" without traffic on trunk road - speed $50 \mathrm{~km} / \mathrm{h}$;

- 1D) Calculation of the "current situation" without traffic on trunk road - speed $30 \mathrm{~km} / \mathrm{h}$.

Alternative with low-noise surface:

- 2A) Calculation of the "current situation" with installed low-noise surface on trunk road - all roads speed $50 \mathrm{~km} / \mathrm{h}$;

- 2B) Calculation of the "current situation" with installed low-noise surface on trunk road - trunk road $50 \mathrm{~km} / \mathrm{h}$, urban road $30 \mathrm{~km} / \mathrm{h}$;

- 2C) Calculation of the "current situation" with installed low-noise surface on all roads - all roads speed $50 \mathrm{~km} / \mathrm{h}$;

- 2D) Calculation of the "current situation" with installed low-noise surface on all roads without traffic on trunk road - speed $50 \mathrm{~km} / \mathrm{h}$.

Alternative with an anti-noise barrier (3 $\mathrm{m}$ height):

- 3A) Calculation of the "current situation" with an anti-noise barrier along trunk road all roads speed $50 \mathrm{~km} / \mathrm{h}$;

- 3B) Calculation of the "current situation" with an anti-noise barrier along trunk road trunk road $50 \mathrm{~km} / \mathrm{h}$, urban road speed $30 \mathrm{~km} / \mathrm{h}$.

To calculate noise maps and the overall noise impact on the population for the "current situation" in the model area in SoundPLAN software, the hourly traffic volumes during the day in accordance with Figure 2 were used. The calculation is simulated on a model area surrounded by a busy trunk road. The urban area consists of detached houses and blocks of flats with a maximum height of 5 floors with the usual community amenities - garages, small shops, etc. The assessment concerns just the noise from car traffic, no other impacts are considered (railway noise, industrial noise, household noise, etc.). 


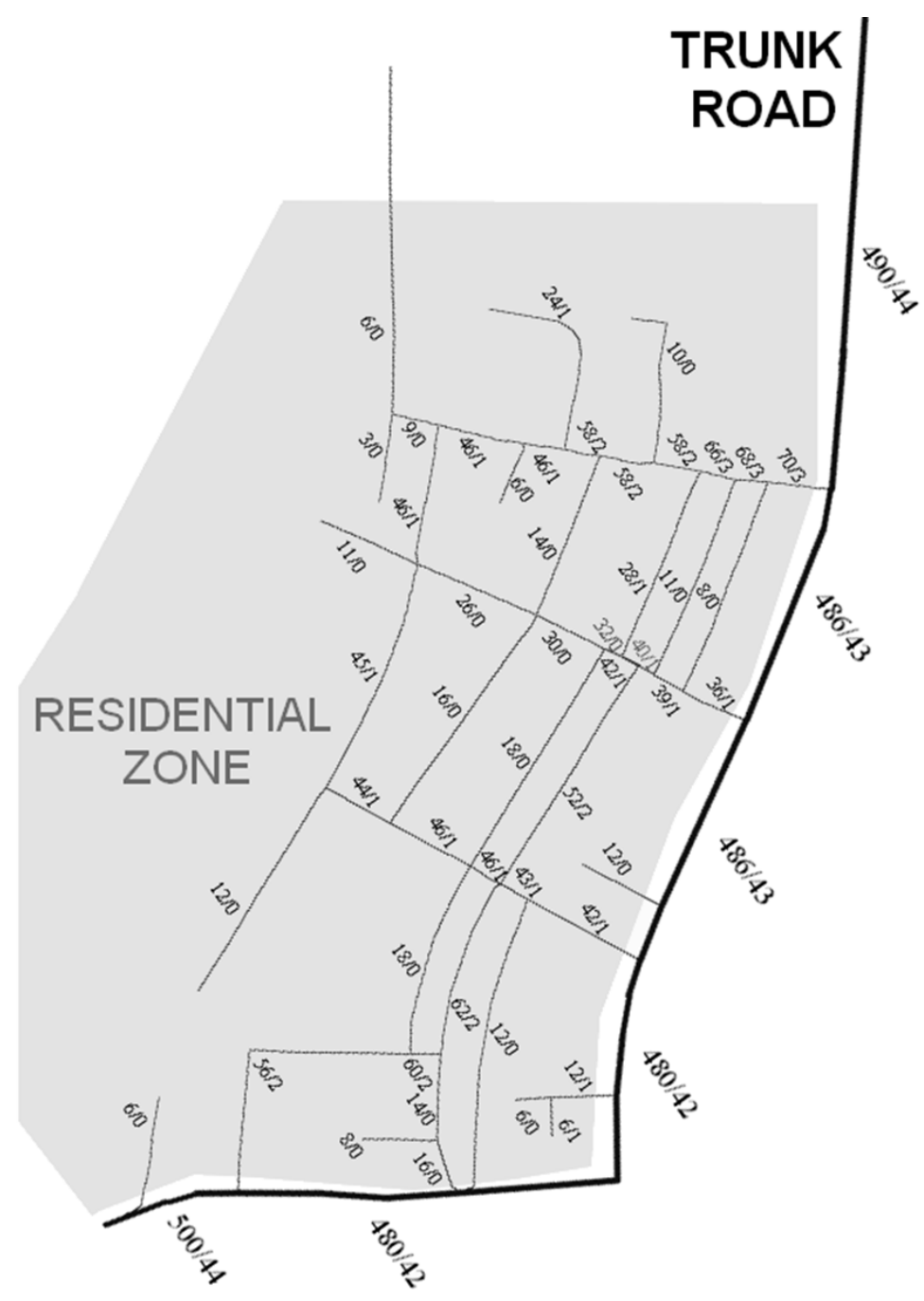

Figure 2: Hourly daily traffic volumes for the model area for the "current situation".

\section{CONCLUSION}

Table 2 shows the number of inhabitants affected by noise in a given zone for individual model situations. The determination of the number of inhabitants affected by traffic noise in an individual two-decibel zone is then given by the cumulative data loading on the number of inhabitants affected by noise in all monitored entities (flats or houses). Subsequently, it is possible to assess the traffic noise impact and assess the designed anti-noise measures and their contribution to the reduction of impact of noise on the population.

The speed reduction from $50 \mathrm{~km} / \mathrm{h}$ to $30 \mathrm{~km} / \mathrm{h}$ in a residential area with a neighbouring busy road is unable to reduce noise levels in the most affected zone. Furthermore, the noise reduction through this measure in a residential area is not very effective due to synergic effects of the trunk road. With the low-noise road surface on the trunk road, it is possible to reduce the number of affected inhabitants in the most affected zone with a partial impact over the first line of the residential area. The low-noise road surface and the speed reduction from $50 \mathrm{~km} / \mathrm{h}$ to $30 \mathrm{~km} / \mathrm{h}$ on the trunk road in a residential area brings about a significant shift of the number of noise affected inhabitants to lower zone along its range, see Figure 3. 
Table 2: Table of inhabitants affected by traffic noise in the model area for individual alternatives.

\begin{tabular}{|c|c|c|c|c|c|c|c|c|c|c|c|c|c|c|c|c|c|c|}
\hline Alternative & $\mathrm{L}_{d}[\mathrm{~dB}(\mathrm{~A})]$ & below 42 & $42-43.9$ & $44-45.9$ & $46-47.9$ & $48-49.9$ & $50-51.9$ & $52-53.9$ & $54-55.9$ & $96-57.9$ & $58-59.9$ & $60-61.9$ & $62-63.9$ & $64-65.9$ & $66-67.9$ & $68-79.9$ & 9 above 70 & Total \\
\hline V01A & No. of inhabitants & 29 & 12 & 469 & 188 & 521 & 581 & 621 & 538 & 423 & 510 & 353 & 399 & 933 & 345 & 3 & 2 & 5927 \\
\hline V01B & No. of inhabitants & 36 & 223 & 351 & 368 & 505 & 530 & 470 & 500 & 473 & 439 & 350 & 399 & 933 & 345 & 3 & 2 & 5927 \\
\hline V01C & No. of inhabitants & 1358 & 397 & 635 & 365 & 706 & 796 & 711 & 498 & 289 & 167 & 5 & 0 & 0 & 0 & 0 & 0 & 5927 \\
\hline V01D & No. of inhabitants & 1392 & 615 & 502 & 512 & 605 & 674 & 759 & 477 & 254 & 135 & 2 & 0 & 0 & 0 & 0 & 0 & 5927 \\
\hline V02A & No. of inhabitants & 29 & 31 & 450 & 191 & 530 & 710 & 588 & 623 & 798 & 554 & 681 & 563 & 174 & 5 & 0 & 0 & 5927 \\
\hline V02B & No. of inhabitants & 36 & 253 & 321 & 371 & 528 & 621 & 473 & 586 & 846 & 472 & 678 & 563 & 174 & 5 & 0 & 0 & 5927 \\
\hline $\mathrm{V} 02 \mathrm{C}$ & No. of inhabitants & 122 & 488 & 331 & 554 & 838 & 545 & 186 & 585 & 489 & 373 & 674 & 563 & 174 & 5 & 0 & 0 & 5927 \\
\hline V02D & No. of inhabitants & 2035 & 586 & 480 & 667 & 1101 & 516 & 199 & 305 & 38 & 0 & 0 & 0 & 0 & 0 & 0 & 0 & 5927 \\
\hline V03A & ants & 29 & 12 & 474 & 188 & 528 & 864 & 839 & 731 & 690 & 718 & 21 & 271 & 332 & 230 & 0 & 0 & 5927 \\
\hline V03B & No. of inhabitants & 36 & 236 & 343 & 368 & 509 & 816 & 700 & 694 & 738 & 636 & 18 & 271 & 332 & 230 & 0 & 0 & 5927 \\
\hline
\end{tabular}

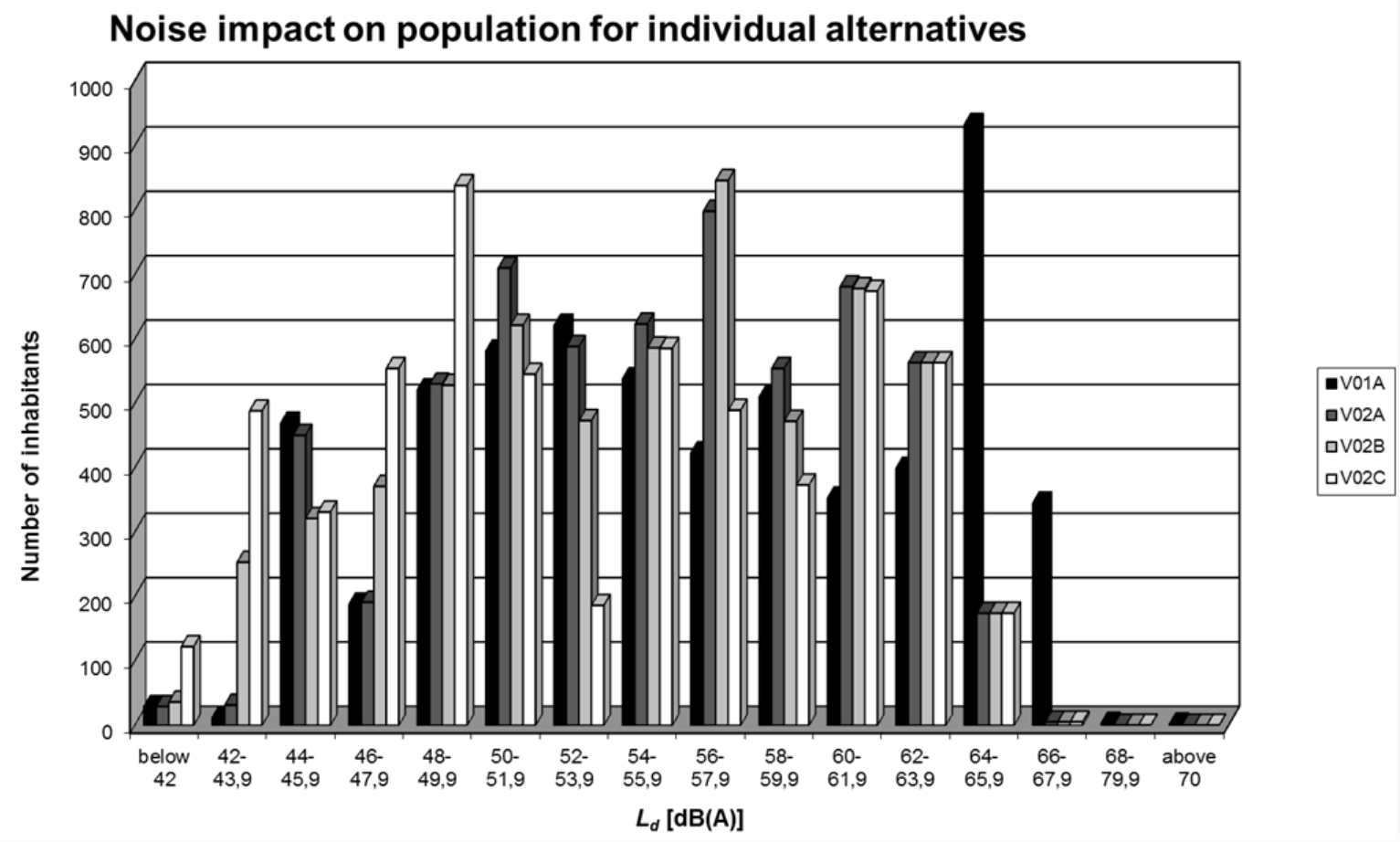

Figure 3: Noise impact on population for low-noise road surface in combination with speed reduction.

The installation of a $3 \mathrm{~m}$ high anti-noise barrier in the vicinity of the trunk road has a partial effect on the number of noise affected inhabitants in the most affected zone. In comparison with the low-noise road surface, this measure is not as effective in the most affected zone due to several reasons. There are a number of turn-off roads to the residential area and the antinoise barrier is not consistent - noise may spread to the residential area through the gaps. Furthermore, a $3 \mathrm{~m}$ high anti-noise barrier is unable to protect multi-storey buildings this measure is totally ineffective for higher floors. Regarding the aggregation of data over more zones, see Figure 4, this measure shows a higher effectiveness, which stems from noise damping behind the obstacle of an anti-noise barrier. In this case the impact of noise is reduced over several zones. 
Noise impact on population for individual alternatives at the aggregation in $10 \mathrm{~dB}$ zone
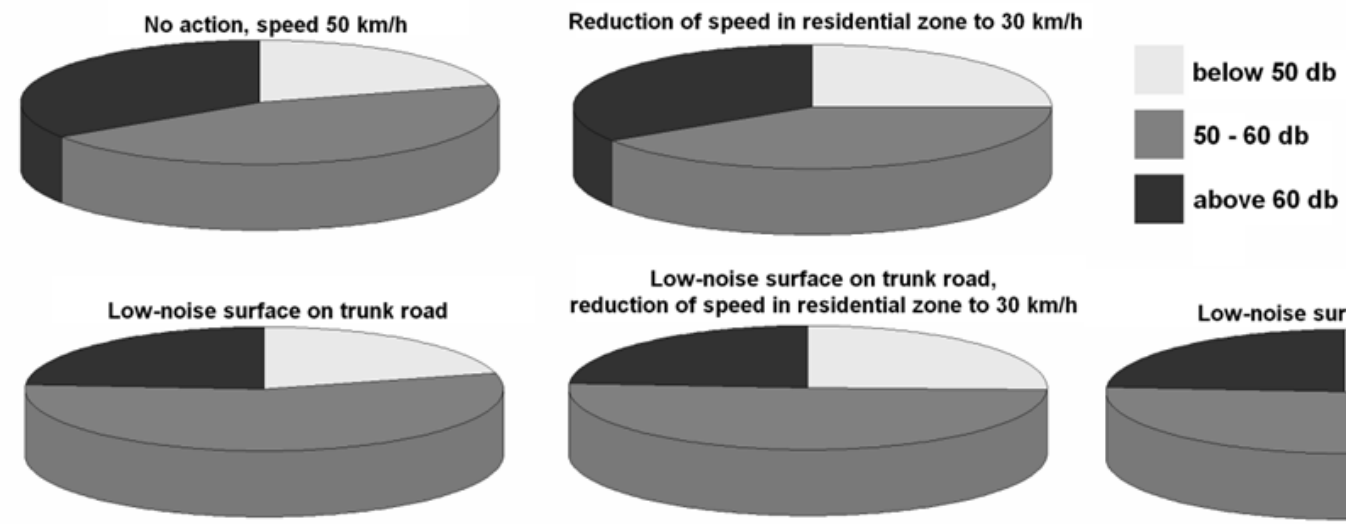

Low-noise surface on trunk road, reduction of speed in residential zone to $30 \mathrm{~km} / \mathrm{h}$
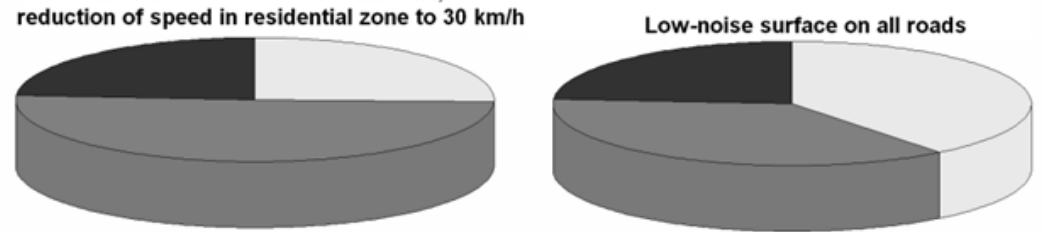

Noise barrier along trunk road

Noise barrier along trunk road,

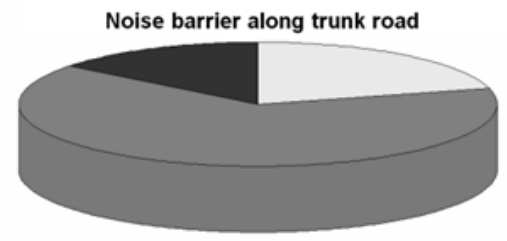

reduction of speed in residential zone to $30 \mathrm{~km} / \mathrm{h}$

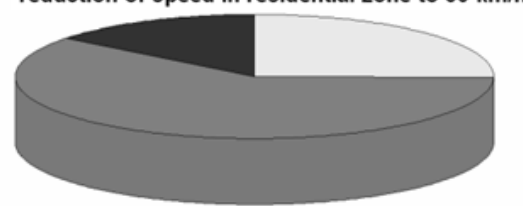

Figure 4: Noise impact on population for individual alternatives at the aggregation in $10 \mathrm{~dB}$ zone.

\section{ACKNOWLEDGEMENTS}

The research described in this article was established within the research project of the Technology Agency of the Czech Republic TA01030459 "Change of noise from road surfaces over several years of use".

\section{REFERENCES}

Act No. 258/2000 Sb. Zákon o ochraně veřejného zdraví. [The Protection of Public Health]. (in Czech)

Act No. 272/2011 Sb. Nařizení č. 272/2011 Sb. o ochraně zdraví před nepř́znivými účinky hluku a vibrací. [Health protection against the adverse effects of noise and vibration] (in Czech)

Braunstein+Berndt GmbH, 2008. SoundPLAN LCC. User's Manual SoundPLAN. 532 p. Germany: Backang.

ČSN ISO 1996-1, 2004. Akustika - Popis, měření a hodnoceni hluku prostředí - Část 1: Základni veličiny a postupy pro hodnocení. [Acoustic - Description, measurement and assessment of environmental noise - Part 1: Basic quantities and assessment procedures]. Czech Standards Institute. (in Czech)

ČSN ISO 1996-2, 2009. Akustika - Popis, měření a posuzování hluku prostředí - Část 2: Určování hladin hluku prostředí. [Acoustic - Description, measurement and assessment 
of environmental noise. Part 2: Determination of environmental noise levels]. Czech Standards Institute. (in Czech)

FEHRL, 2008. Report on state-of-the-art test methods, Seventh Framework Programme, FP7217920. Netherlands: FEHRL.

Křivánek, V. et al., 2012. Změna hluku povrchů vozovek v průběhu několika let používání: Prưběžná zpráva. [Changing noise road surfaces over several years: Progress report]. Brno: Transport Research Centre (CDV). 109 p. Submitter: Technology Agency of Czech Republic. (in Czech)

Ládyš, L. et al., 2006. Systémová podpora interaktivního ovlivňování vývoje hlukové situace $v$ okolí dálnic a silnic I. tř́dy. Praha: Ekola group, spol. s r.o. (in Czech).

Methodological guidance of the measurement and evaluation of noise in out-working environment of 11. 12. 2001, č.j. HEM-300-11.12.01-34065. (in Czech)

Striegler, R. et al., 2009. Methodology surface traffic calming. Annex 1, Identification of sites for measurement, the actual measurement and evaluation of measured data. Brno: Transport Research Centre, pp. 110-184. Submitter: Ministry of Transportation of Czech. (in Czech) 